\title{
Correction to: Digital Economy as a Factor in the Technological Development of the Mineral Sector
}

\author{
V. S. Litvinenko $\mathbb{1}^{1,2}$ \\ Correction to: \\ Natural Resources Research (2020) 29: 1521-1541 \\ https://doi.org/10.1007/s11053-019-09568-4
}

The article Digital Economy as a Factor in the Technological Development of the Mineral Sector, written by V. S. Litvinenko, was originally published electronically on the publisher's Internet portal on October 23, 2019, without open access. With the decision of the author(s) to opt for Open Choice, the copyright of the article changed on June 30, 2020, to (C) The Author(s) 2020 and the article is forthwith distributed under a Creative Commons Attribution 4.0 International License (https://creativecommons. org/licenses/by/4.0/), which permits use, sharing, adaptation, distribution and reproduction in any medium or format, as long as you give appropriate credit to the original author(s) and the source, provide a link to the Creative Commons license, and indicate if changes were made.

\footnotetext{
${ }^{1}$ Saint-Petersburg Mining University, Saint Petersburg, Russia.

${ }^{2}$ To whom correspondence should be addressed; e-mail: rectorat@spmi.ru
}

The original article can be found online at https://doi.org/10.1007/ s11053-019-09568-4.

\section{OPEN ACCESS}

This article is licensed under a Creative Commons Attribution 4.0 International License (https://c reativecommons.org/licenses/by/4.0/), which permits use, sharing, adaptation, distribution and reproduction in any medium or format, as long as you give appropriate credit to the original author(s) and the source, provide a link to the Creative Commons licence, and indicate if changes were made. The images or other third party material in this article are included in the article's Creative Commons licence, unless indicated otherwise in a credit line to the material. If material is not included in the article's Creative Commons licence and your intended use is not permitted by statutory regulation or exceeds the permitted use, you will need to obtain permission directly from the copyright holder. To view a copy of this licence, visit http://creativecom mons.org/licenses/by/4.0/.

Publisher's Note Springer Nature remains neutral with regard to jurisdictional claims in published maps and institutional affiliations. 